\title{
Incorporating Collaborative Learning in an English Course Using Whatsapp
}

\section{Noor Sulaiman Syah}

English Education Departmentt, State Islamic Institute, Kudus, Indonesia

\section{Q Sulaiman@iainkudus.ac.id}

\begin{abstract}
In this era, mobile phone is needed in the teaching and learning process. WhatsApp, is the most favored mobile based applications among students, will be the potential application for incorporating collaborative learning. Therefore, this study aims to explore the incorporation of collaborative learning in an English course using WhatsApp and to identify the students' perception toward that tool in an English course. This case study was conducted in the Arabic Education department of IAIN Kudus, on second semester students of 2019/2020. Two different sources of data were used to collect the information needed for answering the research questions. They were analysis of participants' posts on the WhatsApp group platform and survey questionnaire using Likert scale. The quantitative data from the response of Likert scale questionnaires is also analyzed qualitatively. Tthe study shows that WhatsApp is a convenient tool for incorporating collaborative learning and students get positive feelings and intentions.
\end{abstract}

\author{
KEYWORDS: \\ Collaborative Learning; \\ Collaborative Tool; \\ WhatsApp Application; \\ English Course.
}

\section{Introduction}

In the recent decades, almost all aspects of people life are supported by technological advances. Technology becomes one of the significant elements of the people's daily life. Technology is becoming prevalent due to its nature to meet the needs of individuals towards information access and communication. Today, it is not only the education system developed rapidly but also technology has started to shape the way of people life. There is a huge gap between education system in the past five decades and today's education system considering educational aids, teaching methods, motivation strategies, etc. In this era of 
globalization which consists of technological generation, a mobile phone is needed in the teaching and learning process. Mobile devices can support the strengthening of different skills inside a classroom, as well as, increasing positive attitudes with regard to the learning process (Robles, Guerrero, Llinas, \& Montero, 2019).

Students make their mobile phones an inseparable part of themselves. They utilize this to help them interact easily to classmates, teachers, and content (Vaughan \& Lawrence, 2013) with cheaper cost compared to the other devices. A high number of students joining social networks show how immense the students' need is for this network. It takes the social structure from real life to virtual environment and removes the time and space limitations. Thus, the development of mobile versions of these programs has become inevitable. It is started by commonly used web based social networks like Facebook, Twitter, etc. and then enlarged into different dimensions under the messaging application like WhatsApp, BBM, Line, Instagram, etc.

Social networks are rapidly used in education even though they differ structurally to some extent (Boyd \& Ellison, 2007). Additionally, their usability and effects in education began to be examined by some researchers. The studies indicate that social networks, with their diverse features for learning aims, have potentials to provide cooperation and collaborative learning, increase social interaction, interest and motivation, improve students skills, attitudes and academic success, accommodate student-student and student-teacher interaction, support learning anytime and anywhere, provide peer support and feedback, and allow for sharing of information in education.

As it is mentioned previously that although there are a lot of instant messaging applications that can operate on mobile devices, it is seen that WhatsApp application is one of the most favored mobile based applications in the world (Statista, 2020). WhatsApp represents more reliability to users and senders depending on the level of privacy of their conversations which is much better than other social media platforms such as Facebook or Twitter (Lenhart, Madden, Macgill, \& Smith, 2007). 
Some studies examined the impact of using WhatsApp (Aburezeq \& Ishtaiwa, 2013) and (Cetinkaya, 2017), observed teacher-students interaction through WhatsApp (Bouhnik \& Deshen, 2014) and (Robles et al., 2019), examine the effectiveness of using WhatsApp (Fattah, 2015) and (Gon \& Raeka, 2017). In their study, (La Hanisi, Risdiany, Dwi Utami, \& Sulisworo, 2018) emphasize that WhatsApp used in collaborative learning can improve English teaching and learning process. Similarly, Cetinkaya (2017) also notes that WhatsApp can be a useful tool for collaborative learning within the scope of learning anytime and anywhere. Therefore, this study aims to explore the incorporation of collaborative learning in an English course using WhatsApp and to identify the students' perception toward that tool in an English course.

For the demands and challenges of a globally competitive society, teachers and students change the ways of learning, interacting, communicating and working collectively. The dynamic of classroom lectures is changed by utilizing mobile technology as educational tools. Klopfer, Squire and Jenkins (2002) describe numerous features of mobile technology that create unique educational benefits, including: a) portability: can take the device to different locations; b) social interactivity: can use the device to collaborate and exchange information with others; $c$ ) context sensitivity: can use it to collect and gather real or simulated data that is appropriate to a specific location, environment and time; d) connectivity: can use it to connect to data collection devices, other devices, and to a network; and e) individuality: can provide scaffolding for learners which is customized to the individual's need. Specifically, the convenience, expediency, and immediacy of mobile devices allow students to learn the right thing at the right time at the right place (Seppala \& Alamaki, 2003).

With its easiness and sophisticated features, WhatsApp become the most familiar application within mobile technology. Church and de Oliveira (2013) emphasize this fact and state that WhatsApp has grown in popularity due to its benefits such as, being able to send real-time messages to an individual or groups of friends simultaneously, low-cost, and privacy.

\section{WhatsApp as a Mobile Technology Application}


WhatsApp, a free messenger application, works across multiple platforms like iPhone and android phones, and this application is being widely used among undergraduate students to send multimedia messages like photos, videos, audios along with simple text messages(Lenhart et al., 2007). Providing by WhatsApp application, lots of information can be accessed in real time under the internet facility, and thus, sharing the information through that tool is both instantaneous and convenient.

According to Bere (2012), WhatsApp messenger has the following collaborative features: 1). Multimedia: It allows the user to exchange videos, text messages, images, and voice notes; 2). Group Chat: It supports the interaction of up to 50 group members; 3). Unlimited Messaging: The number of messages you can share on WhatsApp is unlimited. The application uses 3G/EDGE internet data plan or Wi-Fi to ensure continuous data transmission across platforms; 4). CrossPlatform Engagements: Interactions with different devices (personal digital assistants, Smart phones, Galaxy tablets) can message one another through various media (text messages, pictures, videos, voice notes); 5). Offline Messaging: Messages are saved automatically when the device is off or outside the coverage area; 6). No Charges involved: there are no charges involved in using WhatsApp as it uses same internet data plan which is used for email or web browsing; 7). Pins and Users Name: WhatsApp, the user, need not remember passwords or username as it works via phone numbers and integrates with users address books.

\section{Collaborative Learning using WhatsApp}

"Collaborative learning" is an umbrella term for a variety of educational approaches involving joint intellectual effort by students, or students and teachers together (Smith \& MacGregor, 1992). Collaborative learning is an instruction given to the students various ability to work together in the group to reach goals (La Hanisi et al., 2018). In collaborative learning, students usually are working to look for understanding, meanings, or solutions mutually, or creating a product in groups of two or more. Collaborative learning activities vary widely and do not only work together but also require team-work with defined roles to reach group success. Most activities center on students' exploration or application of the course material 
(learner-centered) and not simply the teacher's presentation or explication of it (teacher-centered).

Collaborative learning represents an important alteration from the typical teacher-centered or lecture-centered milieu in college classrooms into learnercentered. Teachers who apply collaborative learning approaches prone think of themselves less as expert transmitters of knowledge to students, and more as expert designers of intellectual experiences for students of a more emergent learning process.

Collaborative activities have the potential to boost more reticent language learners' confidence to participate in classroom activities (Ur, 1996) and to help them maintain their self-esteem, overcome their shyness and lack of selfconfidence, and learn interpersonal relationships. Collaboration activities can be done without face to face learning in the classroom of students and teacher by using collaborative tools. Collaborative tools are usually web-based that can bear group activities with low price, it just needs to use internet access, and there is no requirement to have other additional hardware. Becker and Cline (2005) gives some tools considered as collaborative ones such as e-mail, audio conferencing, collaborative presentation software, conference room video-conferencing, desktop video conferencing, discussion database, document management software, electronic white boarding, group authoring, GDSS, group scheduling and calendaring, knowledge management systems, one-way bulletin boards (BBS), personal communication tools like laptop, mobile phone, pagers, and so on. One of the mobile phone and web-based instant message applications that can be used as collaborative tool is WhatsApp application.

\section{Method}

The present case study was conducted at second semester of Arabic Education Department of IAIN Kudus, Indonesia. A virtual learning platform supported by WhatsApp social networking was created as a primary tool to English course for this semester around the Covid 19 pandemic. The teacher created the WhatsApp group platform and prepared the students to function it. WhatsApp group was mainly adapted for allowing students to connect with classmates, teacher and 
content. Students academically collaborated through posting content of presentation related to English course, supporting their posts with resources (videos, audios, pictures, websites, etc.), discussing course content, asking questions, responding to questions, and commenting on daily lectures. The investigation covers 26 students of English course during the second semester of 2019-2020. All postings including ideas, thoughts, responses, comments, audio and video clips and threads were available to the teacher to view throughout the semester.

Two different sources of data were used to collect the information needed for answering the research questions. They were analysis of participants' posts on the WhatsApp group platform and survey questionnaire using Likert scale.

The first answer of the research questions in this study described the process of teaching learning activities in English course through the participants' posts on the WhatsApp group platform. The activities included listening, speaking, reading and writing skills. The second answer analyzed and described the questionnaires' responses using Likert scale. Likert scale is developed in 1932 by Rensis Likert to measure attitudes, the typical Likert scale is a 5 or 7 point ordinal scale used by respondents to rate the degree to which they agree or disagree with a statement (Sullivan \& Artino Jr, A, 2013). Likert scale is designed to measure people's attitudes, opinions, or perceptions. It is widely used in social and educational research.

The quantitative data from the response of Likert scale questionnaires then is analyzed qualitatively. The questionnaires questions dealt with the following areas of inquiry: 1) advantages of WhatsApp as teaching learning tool; and 2) challenges faced by the learners on using WhatsApp as a teaching learning tool.

\section{Finding}

\begin{tabular}{|l|l|c|c|c|c|c|}
\hline SN & $\begin{array}{c}\text { Advantages/ } \\
\text { Subcategories }\end{array}$ & $\begin{array}{c}\text { Strongly } \\
\text { Agree }\end{array}$ & Agree & Neutral & Disagree & $\begin{array}{c}\text { Strongly } \\
\text { Disagree }\end{array}$ \\
\hline \multicolumn{7}{|c|}{ Technical } \\
\hline \multirow{2}{*}{1} & Simple to use & $15.38 \%$ & $73.07 \%$ & $11.53 \%$ & - & - \\
\cline { 2 - 7 } & Free of charge & - & $7.69 \%$ & $19.23 \%$ & $50 \%$ & $23.07 \%$ \\
\cline { 2 - 7 } & $\begin{array}{l}\text { Easily available } \\
\text { and downloadable }\end{array}$ & $34.61 \%$ & $30.76 \%$ & $15.38 \%$ & $7.69 \%$ & $11.53 \%$ \\
\cline { 2 - 8 } & Privacy & $7.69 \%$ & $42.30 \%$ & $26.92 \%$ & $15.38 \%$ & $7.69 \%$ \\
\hline
\end{tabular}




\begin{tabular}{|c|c|c|c|c|c|c|}
\hline & Already using it & $50 \%$ & $50 \%$ & - & - & - \\
\hline \multicolumn{7}{|c|}{ Educational } \\
\hline \multirow[t]{5}{*}{2} & $\begin{array}{l}\text { Conducive } \\
\text { environment }\end{array}$ & $7.69 \%$ & $46.15 \%$ & $34.61 \%$ & $11.53 \%$ & - \\
\hline & $\begin{array}{l}\text { Sense of } \\
\text { belonging to the } \\
\text { group }\end{array}$ & $11.53 \%$ & $23.07 \%$ & $26.92 \%$ & $19.23 \%$ & $19.23 \%$ \\
\hline & $\begin{array}{l}\text { Interaction } \\
\text { between students, } \\
\text { sharing learning } \\
\text { material }\end{array}$ & $7.69 \%$ & $76.92 \%$ & $11.53 \%$ & $3.84 \%$ & - \\
\hline & $\begin{array}{l}\text { High interaction } \\
\text { with facilitator }\end{array}$ & $7.69 \%$ & $53.84 \%$ & $23.07 \%$ & $15.38 \%$ & - \\
\hline & $\begin{array}{l}\text { Doubts } \\
\text { immediately } \\
\text { cleared }\end{array}$ & $11.53 \%$ & $50 \%$ & $30.76 \%$ & $7.69 \%$ & - \\
\hline \multicolumn{7}{|c|}{ Instructional } \\
\hline \multirow[t]{4}{*}{3} & $\begin{array}{l}\text { Easy accessibility } \\
\text { to learning } \\
\text { material }\end{array}$ & $11.53 \%$ & $73.07 \%$ & $7.69 \%$ & $7.69 \%$ & - \\
\hline & $\begin{array}{l}\text { Facilitator's } \\
\text { availability }\end{array}$ & $38.46 \%$ & $50 \%$ & $11.53 \%$ & - & - \\
\hline & $\begin{array}{l}\text { Learning anytime } \\
\text { anywhere }\end{array}$ & $76.92 \%$ & $11.53 \%$ & $7.69 \%$ & $3.84 \%$ & - \\
\hline & $\begin{array}{l}\text { Provide secure } \\
\text { environment }\end{array}$ & $7.69 \%$ & $46.15 \%$ & $38.46 \%$ & $7.69 \%$ & - \\
\hline
\end{tabular}

Table 1. Advantages of WhatsApp as teaching learning tool

\begin{tabular}{|c|c|c|c|c|c|c|}
\hline SN & $\begin{array}{c}\text { Challenges/ } \\
\text { Subcategories }\end{array}$ & $\begin{array}{c}\text { Strongly } \\
\text { Agree }\end{array}$ & Agree & Neutral & Disagree & $\begin{array}{l}\text { Strongly } \\
\text { Disagree }\end{array}$ \\
\hline \multicolumn{7}{|c|}{ Technical } \\
\hline \multirow[t]{5}{*}{1} & No smart phone & $57.69 \%$ & $26.92 \%$ & $11.53 \%$ & $3.84 \%$ & - \\
\hline & Message flooding & $61.53 \%$ & $15.38 \%$ & $11.53 \%$ & $3.84 \%$ & $7.69 \%$ \\
\hline & Time consuming & $53.84 \%$ & $15.38 \%$ & - & $11.53 \%$ & $19.23 \%$ \\
\hline & $\begin{array}{l}\text { Group } \\
\text { maintenance }\end{array}$ & $34.61 \%$ & $15.38 \%$ & $23.07 \%$ & $3.84 \%$ & $23.07 \%$ \\
\hline & Eye strain & $53.84 \%$ & $11.53 \%$ & $7.69 \%$ & $15.38 \%$ & $11.53 \%$ \\
\hline \multicolumn{7}{|c|}{ Educational } \\
\hline \multirow[t]{2}{*}{2} & $\begin{array}{l}\text { High expectation } \\
\text { of teacher's } \\
\text { availability }\end{array}$ & $42.30 \%$ & $19.23 \%$ & $15.38 \%$ & $11.53 \%$ & $11.53 \%$ \\
\hline & $\begin{array}{l}\text { Huge amount of } \\
\text { learning material } \\
\text { makes it confusing }\end{array}$ & $26.93 \%$ & $30.76 \%$ & $23.07 \%$ & $19.23 \%$ & - \\
\hline
\end{tabular}




\begin{tabular}{|c|l|c|c|c|c|c|}
\hline & $\begin{array}{l}\text { Use of } \\
\text { inappropriate } \\
\text { language }\end{array}$ & - & $7.69 \%$ & $11.53 \%$ & $3.84 \%$ & $76.92 \%$ \\
\hline Instructional & $\begin{array}{l}\text { No efforts by } \\
\text { some students }\end{array}$ & $3.84 \%$ & $50 \%$ & $23.07 \%$ & $11.53 \%$ & $11.53 \%$ \\
\cline { 2 - 6 } & $\begin{array}{l}\text { Some students } \\
\text { share materials to } \\
\text { impress facilitator } \\
\text { without actually } \\
\text { learning about it }\end{array}$ & - & $50 \%$ & $34.61 \%$ & $15.38 \%$ & - \\
\hline
\end{tabular}

Table 2. Challenges faced by the students on using WhatsApp as teaching learning tool

\section{Discussion}

\section{Activities in an English Course}

In listening skill, technology offers a number of electronic tools in and outside the classroom that can help in the teaching and learning process(Chun, Kern, \& Smith, 2016). By the help of technology, teacher plays the role as the facilitator who lets the students to be more active in engaging the English course. Teacher and students engaged in the following actions: 1) teacher asked the students (presenters) to share their audio recording of their presentation and asked other students to listen to it; 2) teacher asked the students (presenters) to share English conversation video and asked other students to watch and listen to it; 3 ) teacher asked students to give the comment or discuss the question based on the video and audio of presentation.

IWhatsApp Application offers its features for learning speaking. In speaking skill, students can discuss using chat room on the WhatsApp group. The teacher provided a certain theme for learning activities. The teacher continued asking them to record the voice, before sending to WhatsApp group. The operations are conducted in these ways: 1) the students (presenters) recorded their audio presentation and shared to the WhatsApp group; 2) for improving students' speaking performance, the teacher allowed other students to ask questions dealing the material of the presentation in the form of voice note; 3 ) then the presenters answered directly the given questions using voice note, too; 4) finally they discussed it in the repeated voice notes. 
In enhancing reading skills of students, the teacher sent a simple reading text, usually taken from online English media, in the WhatsApp group. The text was valuable to provide students exercises for enhancing their vocabulary and reading. To help students acquiring more vocabulary, teacher conducted the following activities: 1) asked the students to read the text from online English media and understand it; 2) asked the students to find the definition of some words; 3 ) students then were asked to practice using the words they know. What students read gives them the chance to come up with their insights and help them speak the language in the more imaginative way. Students would be more creative since they are faced with their point of view.

WhatsApp technology can improve students' active participation in the online classroom. It gives students a chance for practicing the language for free, a more personal and comprehensive relationship between students and teachers, an opportunity for students to be more sociable, to learn better, and to synchronize their opinions with others. In developing students' writing skill, teacher facilitated a variety of writing activities in WhatsApp group: 1) teacher asked students to write comments or express their idea based on the text of English online media they read; 2) students were also asked to share their comment and are responded to classmates in written text; 3 ) teacher gave the feedback to students' writing; and 4) students were also asked to write any responses raised by the teacher in the group discussion of WhatsApp.

\section{Students' Perception towards the Use of WhatsApp as a Learning Tool}

For the survey questionnaire, twenty four questions were asked to students. The questions dealt with the advantages of WhatsApp as teaching learning tool and challenges faced by the learners on using WhatsApp as a teaching learning tool.

Table 1 and Table 2 describes the perception of the learners $(n=26)$ about WhatsApp as learning tool along with its advantages and challenges faced on its application as a learning tool. Both the advantages and challenges were measured on the scale of 1 to 5 with 1 referring to strongly disagree, 2 to disagree, 3 to neutral, 4 to agree and 5 to strongly agree. The all twenty six students (100\%) were already using WhatsApp for other social activities. Twenty two students (84.61\%) 
and sixteen students (61.53\%) agreed on high interaction between themselves as well as with the facilitator during teaching learning activity respectively. Also, more than $60 \%$ students concurred that WhatsApp provides easy accessibility to learning material as well as facilitator, and doubts if any can be cleared immediately. Facilitator's availability and learning anytime anywhere were top two advantages of learning through WhatsApp with $88.46 \%$ and $88.45 \%$ students agreeing to it. Mobile learning increases the flexibility of accessing a variety of resources for learning independently at anytime and anywhere (Jardat, 2014). Amongst technical advantages, most of the students agreed that WhatsApp is simple to use and easily available and downloadable but $73.07 \%$ students disagreed that it is free of charge as they had to study from home around this Covid 19 pandemic time and they had to take packages with mobile data which had cost slightly more than the plan without mobile data.

There were many challenges faced by the learners on using WhatsApp as teaching learning tool (Table 2 ) with more than $60 \%$ learners agreeing on technical challenges comprising availability of smart phones, message flooding, time consuming and continuous focusing towards the mobile screen leading to ocular muscle fatigue. Also, $53.84 \%$ and $50 \%$ learners concurred that there were no efforts by some students and some learners only share material to impress the facilitator. Use of inappropriate language was not witnessed in the present study with $80.76 \%$ students denying it.

\section{Conclussion}

This study has highlighted the infiltration of mobile phone that has initiated the growing use of WhatsApp for educational purposes. It shows that WhatsApp is beneficial to students' knowledge of the language. The blend of medium like videos, pictures and voice notes along with facilitator's availability and learning anytime anywhere, has made WhatsApp a convenient tool for incorporating collaborative learning in English course..

Bouhnik and Deshen (2014) states that the advantages to the use of WhatsApp in teaching is the broad availability of the teacher to the students, the opportunity for students to help one another, and the opportunity for more in-depth acquaintance with the students on the educational and personal levels. Therefore, 
students as the participants have positive perceptions of the proper use of WhatsApp to sustain their learning. In other word, the integration of WhatsApp into their education will be easy, fun, and useful. Students get positive feelings and intentions regarding the potential use of WhatsApp in their learning.

\section{References}

Aburezeq, I. M., \& Ishtaiwa, F. . (2013). The impact of WhatsApp on interaction in an Arabic language teaching course. International Journal of Arts \& Sciences, 6(3), 165-180.

Becker, J. D., \& Cline, M. (2005). Effectiveness of collaborative tool usage for virtual team activities. AMCIS 2005 Proceedings, Vol. 3. Omaha: Association for Information System.

Bere, A. (2012). A comparative study of student experiences of ubiquitous learning via mobile devices and learner management systems at a South African university. In Proceedings of the 14th Annual Conference on World Wide Web Applications (pp. 4-17). Durban, South Africa: Cape Peninsula University of Technology.

Bouhnik, D., \& Deshen, M. (2014). WhatsApp goes to school: Mobile instant messaging between teachers and students. Journal of Information Technology Education: Research, 13, 217-231. Retrieved from https://doi.org/10.28945/2051

Boyd, D. M., \& Ellison, N. B. (2007). Social network sites: Definition, history, and scholarship. Journal of Computer-Mediated Communication, 13(1), 210-230. https://doi.org/http://dx.doi.org/10.1111/j.1083-6101.2007.00393.x

Cetinkaya, L. (2017). The Impact of WhatsApp Use on Success in Education Process. International Review of Research in Open and Distributed Learning, 18(7), 59-74.

Chun, D., Kern, R., \& Smith, B. (2016). Technology in language use, language teaching, and language learning. The Modern Language Journal, 100(1), 6480. https://doi.org/https://doi.org/10.1111/modl.12302

Church, K., \& de Oliveira, R. (2013). What's up with WhatsApp? Comparing mobile instant messaging behaviors with traditional SMS. In Proceedings of the 15th International Conference on Human Computer Interaction with Mobile Devices and Services (pp. 352-361).

https://doi.org/http://dx.doi.org/10.1145/2493190.2493225

Fattah, S. F. E. S. A. (2015). The effectiveness of using WhatsApp messenger as one of mobile learning techniques to develop students' writing skills. Journal of Education and Practice, 6(32), 115-127.

Gon, S., \& Raeka, A. (2017). Effectivity of E-Learning through WhatsApp as a Teaching Learning Tool. MVP Journal of Medical Sciences, 4(1), 19-25. https://doi.org/DOI: 10.18311/mvpjms/2017/v4i1/8454. 
Klopfer, E., Squire, K., \& Jenkins, H. (2002). Environment detectives: PDAs as a window into a virtual simulated world. In IEEE International Workshop on Wireless and Mobile Technologies in Education (pp. 95-98). Vaxjo, Sweden: IEEE Computer Society.

La Hanisi, A., Risdiany, R., Dwi Utami, Y., \& Sulisworo, D. (2018). The use of WhatsApp in collaborative learning to improve English teaching and learning process. International Journal of Research Studies in Educational Technology, 7(1), 29-35. https://doi.org/10.5861/ijrset.2018.3004.

Lenhart, A., Madden, M., Macgill, A., \& Smith, A. (2007). Teens and social media. New York: New York Press.

Robles, H., Guerrero, J., Llinas, H., \& Montero, P. (2019). Online teacher-students interactions using WhatsApp in a law course. Journal of Information Technology Education, 18, 231-252. https://doi.org/https://doi.org/10.28945/4321

Seppala, P., \& Alamaki, H. (2003). Mobile learning in teacher training. Journal of Computer Assisted Learning, 19, 330-335.

Smith, B. L., \& MacGregor, J. (1992). "What Is Collaborative Learning?" in Collaborative Learning: A Sourcebook for Higher Education, by Anne Goodsell, Michelle Maher, Vincent Tinto, Barbara Leigh Smith and Jean MacGregor. Pennsylvania State University.

Statista. (2020). Most popular global mobile messaging apps 2019. Retrieved from https://www.statista.com/statistics/258749/most-popular-globalmobile-messenger-apps/

Sullivan, G. ., \& Artino Jr, A, R. (2013). Analyzing and Interpreting Data from LikertType Scales. Journal of Graduate Medical Education, 5(4), 542.

Ur, P. (1996). A course in language teaching: Practice and theory. Cambridge: Cambridge University Press.

Vaughan, N., \& Lawrence, K. (2013). Investigating the role of mobile devices in a blended pre-service teacher education program. Canadian Journal of Higher Education, 43(3), 56-77. 